\title{
PERANCANGAN SISTEM PAKAR UNTUK IDENTIFIKASI GANGGUAN HAMA DAN PENYAKIT PADI (ORYZA SATIVA) MENGGUNAKAN METODE FORWARD CHAINING.
}

\author{
Agusman ${ }^{1}$, Ilyas ${ }^{2}$ \\ 1,2Program Studi Sistem Informasi, Universitas Islam Indragiri, Tembilahan \\ Email: agus.foto@yahoo.co.id (korespondensi)
}

\begin{abstract}
With the development of science and technology, this pest and rice disease information can not only be obtained through consultation with experts, but also can be known through an expert system. This will help the consumer to facilitate in consultation on diseases and pests of rice plants. The results obtained from this study are: This system can help facilitate the community in detecting damage to his crops caused by pests and diseases. Able to provide diagnostic results based on the symptoms found. Implementation of forward chaining method is able to answer the problem of society in analyzing the type of disease or pest causing damage to rice plant based on the collected knowledge.
\end{abstract}

Keywords: Expert System, forward chaining, rice, oryza sativa.

\begin{abstract}
Abstrak
Dengan perkembangan ilmu pengetahuan dan teknologi, informasi-informasi hama dan penyakit padi ini tidak hanya bisa didapatkan melalui konsultasi pada pakar, tetapi juga dapat diketahui melalui sebuah sistem pakar. Hal ini akan membantu pihak konsumen untuk mempermudah dalam melakukan konsultasi mengenai penyakit dan hama tanaman padi. Hasil yang diperroleh dari penelitian ini yaitu: Sistem ini dapat membantu mempermudah masyarakat dalam mendeteksi kerusakan tanaman padinya yang disebabkan karena adanya gangguan hama dan penyakit. Mampu memberikan hasil diagnosa berdasarkan gejala yang yang ditemukan. Penerapan metode forward chaining mampu menjawab permasalahan masyarakat dalam menganalisis jenis penyakit ataupun hama yang menyebabkan kerusakan pada tanaman padi berdasarkan pengetahuan yang dikumpulkan.
\end{abstract}

Kata kunci: Sistem Pakar, forward chaining, padi, oryza sativa.

\section{PENDAhUluan}

Padi merupakan tanaman pangan berupa rumput berumpun. Tanaman pertanian kuno berasal dari dua benua yaitu Asia dan Afrika Barat tropis dan subtropis. Terdapat banyak jenis oryza sativa yang terdapat di dua benua ini diantaranya IR, PB, Gemar, Gati dan, banyak lagi jenis dari padi. Padi merupakan tanaman yang diolah menjadi beras yang kemudian menjadi makanan pokok.

Kabupaten Indragiri Hilir (Inhil) menjadi lumbung padi dan penyumbang beras terbesar di Provinsi Riau. Produksi beras di Kabupaten Inhil menjadi penyumbang 28 persen kebutuhan beras di provinsi Riau, Total produksi beras di Provinsi Riau sebanyak 434.151 ton dan sebanyak 125.340 ton disumbangkan Inhil.

Untuk mendapatkan kualitas padi yang baik, tentu harus memperhatikan dan dilakukan perawatan dari proses persemaian sampai pada proses panen dilakukan. Hal ini dilakukan karena tantangan yang datang dari gangguan hama dan penyakit padi. Dengan demikian, maka diperlukan informasiinformasi yang berhubungan dengan penyakit dan hama yang dapat menyerang tanama padi. Namun, pada kenyataannya masih kurangnya pengetahuan petani terhadap gangguan hama dan jenis penyakit pada tanaman padi. Dengan perkembangan ilmu
pengetahuan dan teknologi, informasi- 
informasi hama dan penyakit padi ini tidak hanya bisa didapatkan melalui konsultasi pada pakar, tetapi juga dapat diketahui melalui sebuah sistem pakar. Hal ini akan membantu pihak konsumen untuk mempermudah dalam melakukan konsultasi mengenai penyakit dan hama tanaman padi.

Sistem pakar ini dibangun menggunakan metode forward chaining (penalaran maju) yaitu, dengan mengetahui gejalagejala, gangguan hama dan penyakit pada padi yang kemudian mendapatkan hasil akhir sebuah keputusan agar masyarakat bisa memilih jenis padi yang akan ditanam, melakukan tindakan pencegahan gangguan hama untuk menghindari penyakit yang terdapat pada tanaman padi

\section{TINJAUAN PUSTAKA}

Dalam buku "Artificial Intelligence" (Sutojo, et al, 2011). Dikatakan bahwa kecerdasan buatan adalah: "mesin yang mampu berfikir, menimbang tindakan yang akan diambil, dan mampu mengambil keputusan seperti yang dilakukan oleh manusia". Selanjutnya, ada beberapa tujuan kecerdasan buatan menurut para ahli, diantaranya: Winston dan Prendergast (Sutojo dkk, 2011): 1) tujuan dari kecerdasan buatan adalah (Sutojo dkk, 2011): 1) Membuat mesin menjadi lebih pintar (tujuan utama). 2) Memahami apa itu kecerdasan (tujuan ilmiah). 3) Membuat mesin lebih bermanfaat (tujuan enterpreneurial). Berdasarkan pendapat ahli di atas dapat disimpulkan bahwa : "cerdas adalah memiliki pengetahuan, pengalaman, dan penalaran untuk membuat keputusan dan mengambil tindakan. Jadi, agar mesin bisa cerdas (bertindak seperti manusia) maka harus diberi bekal pengetahuan dan diberi kemampuan untuk menalar (Sutojo dkk, 2011).

Istilah sistem pakar berasal dari istilah knowladge-based expert system. System pakar adalah pengetahuan seorang pakar yang dimasukkan ke dalam komputer (Sutojo dkk, 2010). Selain itu, ada beberapa pengertian system pakar menurut para ahli (Sutojo dkk, 2010): (1) Turban. Sistem pakar adalah sebuah sistem yang menggunakan pengetahuan manusia di mana pengetahuan tersebut di masukkan ke dalam sebuah komputer dan kemudian digunakan untuk menyelesaikan masalah-masalah yang biasanya membutuhkan kepakaran atau keahlian manusia. (2) Jackson. Sistem pakar adalah program computer yang mereprentasikan dan melakukan penalaran dengan pengetahuan beberapa pakar untuk memecahkan maslah atau memberikan saran. Ada dua bagian penting dari sistem pakar, yaitu lingkungan pengembang (development environment) dan lingkungan konsultasi (consultan environment). Gambar menunjukkan komponen-komponen yang penting dalam sistem pakar sebagai berikut:

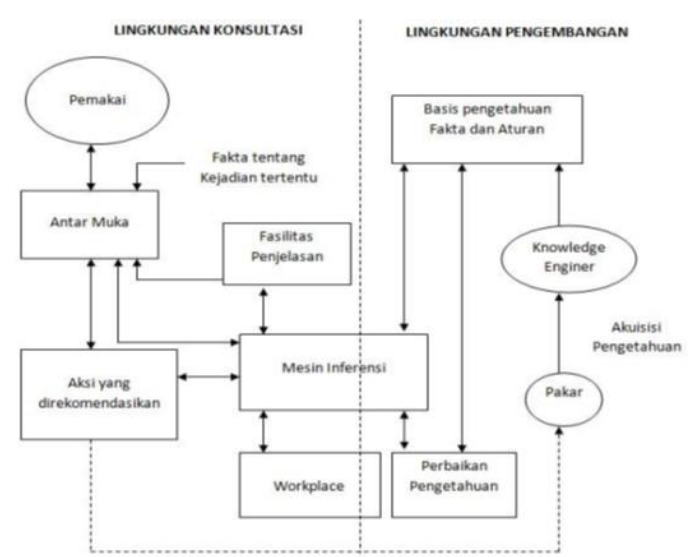

Gambar 1. Komponen-komponen yang Penting dalam Sistem Pakar

Forward chaining (Satwika, 2012). merupakan suatu penalaran yang dimulai dari fakta untuk mendapatkan kesimpulan (conclusion) dari fakta tersebut. Metode inferensi runut maju merupakan strategi pencarian yang memulai proses pencarian dari sekumpulan data atau fakta, dari datadata tersebut dicari suatu kesimpulan yang menjadi solusi dari permasalahan yang dihadapi.

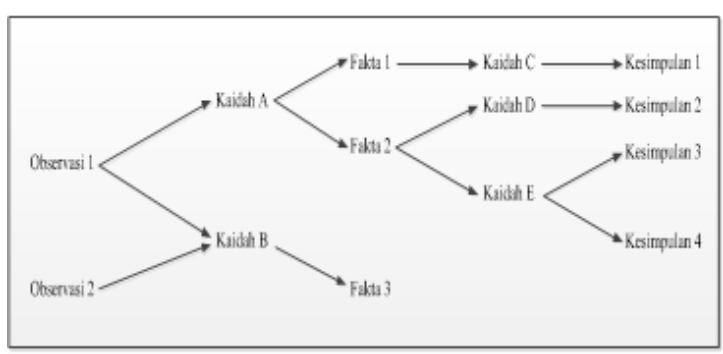

Gambar 2. Proses inferensi runut maju (Widiastuti dkk, 2012)

Proses pengembangan sistem mempunyai beberapa tahapan mulai dari sistem itu direncanakan sampai dengan sistem itu diterapkan, dioperasikan, dan dipelihara. Tahapan-tahapan tersebut dapat dilihat pada Gambar berikut: 


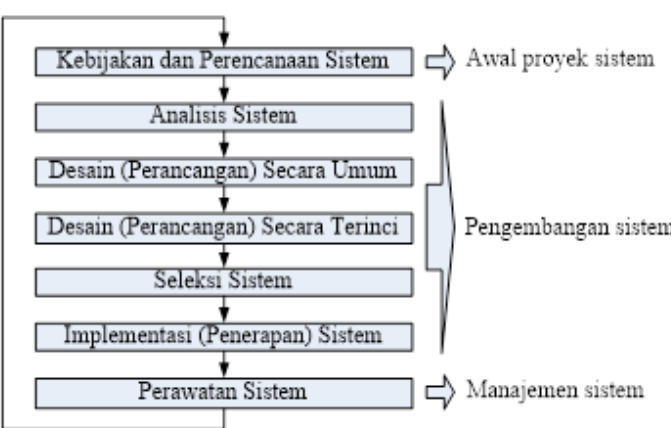

Gambar 3. System Development Life Cycle (SDLC) (Hartono, 2005)

\section{Perancangan Sistem}

Tahap akusisi pengetahuan ini merupakan tahap pengumpulan pengetahuan dari sumber-sumber seperti pakar, buku, jurnal atau dari berbagai sumber. Pengetahuan yang dikumpulkan berkaitan dengan penelusuran bermacam-macam jenis penyakti serta mengamati ciri-ciri yang telah diketahui sebelumnya.

Tabel 1. Basis Pengetahuan Hama-Hama Oryza Sativa

\begin{tabular}{|c|c|c|c|}
\hline Id & Hama & id & Gejala-Gejala \\
\hline $\mathrm{Hm} 1$ & $\begin{array}{l}\text { Hama Putih } \\
\text { (Nymphula depunctalis) }\end{array}$ & $\begin{array}{l}\text { Gh1 } \\
\text { Gh2 } \\
\text { Gh3 }\end{array}$ & $\begin{array}{l}\text { Menyerang daun bibit } \\
\text { Kerusakan berupa titik-titik yang } \\
\text { memanjang sejajar tulang daun } \\
\text { Ulat menggulung daun padi }\end{array}$ \\
\hline $\mathrm{Hm} 2$ & $\begin{array}{l}\text { Padi Trip } \\
\text { (Trips oryzae) }\end{array}$ & $\begin{array}{l}\text { Gh4 } \\
\text { Gh5 } \\
\text { Gh6 }\end{array}$ & $\begin{array}{l}\text { Daun menggulung dan berwarna } \\
\text { kuning sampai kemerahan } \\
\text { Pertumbuhan bibit terhambat } \\
\text { Pada tanaman dewasa gabah tidak } \\
\text { berisi }\end{array}$ \\
\hline $\mathrm{Hm} 3$ & \begin{tabular}{|l|} 
Ulat Tentara \\
(Pseudeletia unipuncta
\end{tabular} & $\begin{array}{l}\text { Gh7 } \\
\text { Gh8 }\end{array}$ & $\begin{array}{l}\text { Ulat memakan helai daun } \\
\text { Tanaman hanya tinggal tulang-tulang } \\
\text { daun }\end{array}$ \\
\hline $\mathrm{Hm} 4$ & $\begin{array}{l}\text { Wereng Padi Coklat } \\
\text { (Nilaparvata lugens }\end{array}$ & $\begin{array}{l}\text { Gh9 } \\
\text { Gh10 } \\
\text { Gh11 }\end{array}$ & $\begin{array}{l}\text { Tanaman padi menjadi kuning dan } \\
\text { mengering } \\
\text { Sekelompok tanaman seperti terbakar } \\
\text { Tanaman yang tidak mengering } \\
\text { menjadi kerdil }\end{array}$ \\
\hline $\mathrm{Hm} 5$ & $\begin{array}{l}\text { Walang Sangit } \\
\text { (Leptocoriza acuta) }\end{array}$ & $\begin{array}{l}\text { Gh12 } \\
\text { Gh13 } \\
\text { Gh14 } \\
\text { Gh15 }\end{array}$ & $\begin{array}{l}\text { Menyebabkan buah hampa atau } \\
\text { berkualitas rendah seperti berkerut } \\
\text { Berwarna coklat dan tidak enak } \\
\text { Pada daun terdapat bercak bekas } \\
\text { isapan } \\
\text { Buah padi berbintik-bintik hitam }\end{array}$ \\
\hline Hm6 & \begin{tabular}{|l|} 
Kepik Hijau \\
(Nezara viridula)
\end{tabular} & $\begin{array}{l}\text { Gh16 } \\
\text { Gh17 } \\
\text { Gh18 }\end{array}$ & $\begin{array}{l}\text { Batang tanaman terdapat bekas } \\
\text { tusukan } \\
\text { Buah padi memiliki noda bekas } \\
\text { isapan } \\
\text { Pertumbuhan tanaman terganggu }\end{array}$ \\
\hline $\mathrm{Hm} 7$ & $\begin{array}{l}\text { Penggerek Batang } \\
\text { (Tryporhyza innotata) }\end{array}$ & $\begin{array}{l}\text { Gh19 } \\
\text { Gh20 } \\
\text { Gh21 } \\
\text { Gh22 }\end{array}$ & $\begin{array}{l}\text { Pucuk tanaman layu } \\
\text { Kering berwarna merah kemerahan } \\
\text { dan mudah dicabut } \\
\text { Daun mengering } \\
\text { Batang mengering }\end{array}$ \\
\hline Hm8 & \begin{tabular}{|l|}
$\begin{array}{l}\text { Hama Tikus } \\
\text { (Rattus argentiventer) }\end{array}$ \\
\end{tabular} & Gh23 & $\begin{array}{l}\text { Adanya tamana padi yang roboh pada } \\
\text { petak sawah }\end{array}$ \\
\hline $\mathrm{Hm} 9$ & Burung & $\begin{array}{l}\text { Gh24 } \\
\text { Gh25 }\end{array}$ & $\begin{array}{l}\text { Tangkai buah patah } \\
\text { Biji berserakan }\end{array}$ \\
\hline
\end{tabular}

Aturan keterangan yang terkait pada pengendalian hama pada tanaman padi ini ditunjukkan pada tabel
Tabel 2. Pengendalian Hama

\begin{tabular}{|c|c|c|}
\hline Id & Hama & Pengendalian Hama \\
\hline Ph1 & $\begin{array}{l}\text { Hama Putih } \\
\text { (Nymphula } \\
\text { depunctalis) }\end{array}$ & $\begin{array}{l}\text { - Melakukan pengeturan air yang baik, penggunaan } \\
\text { bibit sehat, melepaskan musuh alami, dan } \\
\text { menggugurkan tabung daun } \\
\text { - Penyemprotan insektisida Kiltop } 50 \text { EC atau } \\
\text { Tomafur 3G }\end{array}$ \\
\hline $\mathrm{Ph} 2$ & $\begin{array}{l}\text { Padi Trip } \\
\text { (Trips orvzae) }\end{array}$ & $\begin{array}{l}\text { - Penyemprotan insektisida Mipein } 50 \text { WP atau } \\
\text { Dharmacin } 50 \text { WP }\end{array}$ \\
\hline $\mathrm{Ph} 3$ & $\begin{array}{l}\text { Ulat Tentara } \\
\text { (Pseudeletia } \\
\text { unipuncta }\end{array}$ & $\begin{array}{l}\text { - Melakukan cara mekanis dan isektisida Sevin, } \\
\text { Diazenon, Sumithhion dan Agrocide }\end{array}$ \\
\hline $\mathrm{Ph} 4$ & $\begin{array}{l}\text { Wereng Padi } \\
\text { Coklat } \\
\text { (Nilaparvata } \\
\text { lugens }\end{array}$ & $\begin{array}{l}\text { - Bertanam padi serempak, menggunakan varitas tahan } \\
\text { wereng seperti IR } 36, \text { IR 48, IR } 64 \text {, Cimanuk dan } \\
\text { Progo. } \\
\text { - Membersihkan lingkungan, melepas musuh alami } \\
\text { seperti laba-laba, kepinding, dan kumbang lebah } \\
\text { - Penyemprotan insektisida Applaud } 10 \mathrm{WP} \text {, Applaud } \\
\text { 400 FW atau Applaud EC }\end{array}$ \\
\hline $\mathrm{Ph} 5$ & $\begin{array}{l}\text { Walang } \\
\text { Sangit } \\
\text { (Leptocoriza } \\
\text { acuta) }\end{array}$ & $\begin{array}{l}\text { - Bertanam serempak, meningkatkan kebersihan, } \\
\text { mengumpulkan dan memunahkan telur, melepas } \\
\text { musuh alami seperti jangkrik } \\
\text { - Menyemprotkan insektisida Bassa } 50 \quad \text { EC, } \\
\text { Dharmabas } 500 \mathrm{EC} \text {, Dharmacin } 50 \mathrm{WP}, \mathrm{Klitop} 50 \\
\text { EC }\end{array}$ \\
\hline Ph6 & $\begin{array}{l}\text { Kepik Hijau } \\
\text { (Nezara } \\
\text { viridula) }\end{array}$ & $\begin{array}{l}\text { - Mengumpulkan dan memusnahkan telur-telurnya, } \\
\text { menyemprotkan insektisida Curacron } 250 \mathrm{ULV}, \\
\text { Dimilin 25 WP, Larvin WP }\end{array}$ \\
\hline $\mathrm{Ph} 7$ & $\begin{array}{l}\text { Penggerek } \\
\text { Batang } \\
\text { (Tryporhyza } \\
\text { innotata) }\end{array}$ & $\begin{array}{l}\text { - Menggunakan varits tahan, meningkatkan kebersihan } \\
\text { lingkungan, menggenangi sawah selama } 15 \text { hari } \\
\text { setelah panen agar kepompong mati, membakar } \\
\text { jerami } \\
\text { - Menggunakan insektisida Curaterr } 3 \mathrm{G} \text {, Dharmafur } \\
\text { 3G, Furadan } 3 \mathrm{G} \text {, Karphos } 25 \mathrm{EC} \text {, Opetrofur } 3 \mathrm{G}, \\
\text { Tomafur } 3 \mathrm{G}\end{array}$ \\
\hline Ph8 & $\begin{array}{l}\text { Hama Tikus } \\
\text { (Rattus } \\
\text { argentiventer) }\end{array}$ & $\begin{array}{l}\text { - Pergiliran tanaman, sanitasi, gropyokan, melepas } \\
\text { musuh alami seperti ular burung hantu, } \\
\text { menggunakan pestisida dengan tepat, intensif dan } \\
\text { teratur, memberikan umpan beracun seperti seng } \\
\text { fosfat yang dicampur dengan jagung atau beras }\end{array}$ \\
\hline ph9 & Burung & - Mengusir dengan bunyi-bunyian atau orang-orangan \\
\hline
\end{tabular}

Aturan keterangan yang terkait pada pengendalian dan penyebab penyakit pada tanaman padi ini ditunjukkan pada tabel

Tabel 3. Pengendalian dan Penyebab Penyakit Padi

\begin{tabular}{|c|c|c|}
\hline Id & Penyakit & Pengendalian dan Penyebab Penyakit Padi \\
\hline Pp1 & $\begin{array}{l}\text { Bercak daun } \\
\text { Coklat }\end{array}$ & $\begin{array}{l}\text { Penvebab : jamur Helmintosporium orvzae } \\
\text { - Merendam benih didalam air panas, pemupukan } \\
\text { berimbang, menanam padi tahan penyakit ini, } \\
\text { menaburkan serbuk air raksa dan bubuk kapur (2:15) } \\
\text { - Menyemprotkan dengan insektisida Rabcide } 50 \mathrm{WP}\end{array}$ \\
\hline \multirow[t]{2}{*}{ Pp2 } & \multirow[t]{2}{*}{ Blast } & Penvebab: jamur Pyricularia orvzae \\
\hline & & $\begin{array}{l}\text { - Membakar sisa jerami, mengenangi sawah, menanan } \\
\text { varitas unggul sentani, cimandirim IR } 48 \text {, IR } 36 \text {, } \\
\text { memberikan pupuk N di saat pertengahan fase } \\
\text { vegetatif dan fase pembentukan bulir } \\
\text { - Menyemprotkan insektisida Fujiwan } 400 \text { EC, } \\
\text { Fongerene } 50 \mathrm{WP} \text {, Kasumin } 20 \mathrm{AS} \text { atau Rabcide } 50 \\
\text { WP }\end{array}$ \\
\hline \multirow[t]{2}{*}{$\mathrm{Pp} 3$} & \multirow[b]{2}{*}{$\begin{array}{l}\text { Garis coklat } \\
\text { daun } \\
\text { (Narrow } \\
\text { brown leaf } \\
\text { spot) }\end{array}$} & Penvebab: jamur Cercospora oryzae \\
\hline & & $\begin{array}{l}\text { - Menanam padi tahan penyakit ini seperti citarum, } \\
\text { mencelupkan benih ke dalam larutan merkuri } \\
\text { - Menyemprotkan fungisida Benlate T } 20 / 20 \mathrm{WP} \text { atau } \\
\text { Delsene MX 200 }\end{array}$ \\
\hline \multirow[t]{2}{*}{ Pp4 } & \multirow{2}{*}{$\begin{array}{l}\text { Busuk } \\
\text { pelepah daun }\end{array}$} & Penyebab: jam \\
\hline & & $\begin{array}{l}\text { it ini } \\
\text { at pembentukan } \\
\text { Validacin } 3 \mathrm{AS}\end{array}$ \\
\hline \multirow[t]{2}{*}{ Pp5 } & \multirow[t]{2}{*}{ Fusarium } & Penvebab: is \\
\hline & & $\begin{array}{l}\text { - Merenggangkan jarak tanam, mencelupkan benih } \\
\text { pada larutan merkuri }\end{array}$ \\
\hline Pp6 & $\begin{array}{l}\text { Noda / Api } \\
\text { palsu }\end{array}$ & $\begin{array}{l}\text { Penvebab: jamur Ustilaginoidea virens } \\
\text { - Memusnahkan malai yang sakit, menyemprotkan } \\
\text { fungisida pada malai sakit }\end{array}$ \\
\hline \multirow[t]{2}{*}{$\mathrm{Pp} 7$} & \multirow{2}{*}{$\begin{array}{l}\text { Kreselk } \\
\text { Hawar daun }\end{array}$} & pestris pv oryza \\
\hline & & $\begin{array}{l}\text { - Menanam varitas tahan penyakit seperti IR } 36, \mathrm{IR} 46 \text {, } \\
\text { Cisadane, Cipunegara. Menghindari luka mekanis, } \\
\text { sanitasi lingkungan } \\
\text { - Pengendalian kimia dengan bakterisida Stamblex } \\
\text { WP }\end{array}$ \\
\hline \multirow[t]{2}{*}{ Pp8 } & \multirow{2}{*}{$\begin{array}{l}\text { Bakteri daun } \\
\text { bergasir } \\
\text { (Leaf streak) }\end{array}$} & Penvebab: Bakteri $X$ translucens \\
\hline & & \\
\hline \multirow[t]{2}{*}{ Pp9 } & \multirow[t]{2}{*}{ Kerdil } & $\begin{array}{l}\text { Penyebab: virus ditularkan ileh serangga Nilaparvata } \\
\text { lugens }\end{array}$ \\
\hline & & $\begin{array}{l}\text { - Sulit dilakukan, usaha pencegahan dilakukan dengan } \\
\text { memusnahkan tanaman yang terserang ada } \\
\text { memberantas vektor }\end{array}$ \\
\hline \multirow[t]{2}{*}{ Pp10 } & \multirow[t]{2}{*}{ Tungro } & $\begin{array}{l}\text { Penyebab: virus yang ditularkan oleh wereng } \\
\text { Nephotettix impicticeps }\end{array}$ \\
\hline & & $\begin{array}{l}\text { - Menanam padi tahan wereng seperti Kelera, IR } 52 \text {, } \\
\text { IR } 36 \text {, IR } 48 \text {, IR } 54 \text {, IR } 46 \text {, dan IR } 42\end{array}$ \\
\hline
\end{tabular}


Mesin inferensi merupakan proses yang menghasilkan informasi dari fakta yang diketahui atau diasumsikan. Dalam penelitian ini metode inferensi yang digunakan adalah (Forward Chaining). Dan untuk pohon keputusan dari metode inferensi yang digunakan pada penelitian ini terlihat pada Gambar berikut:

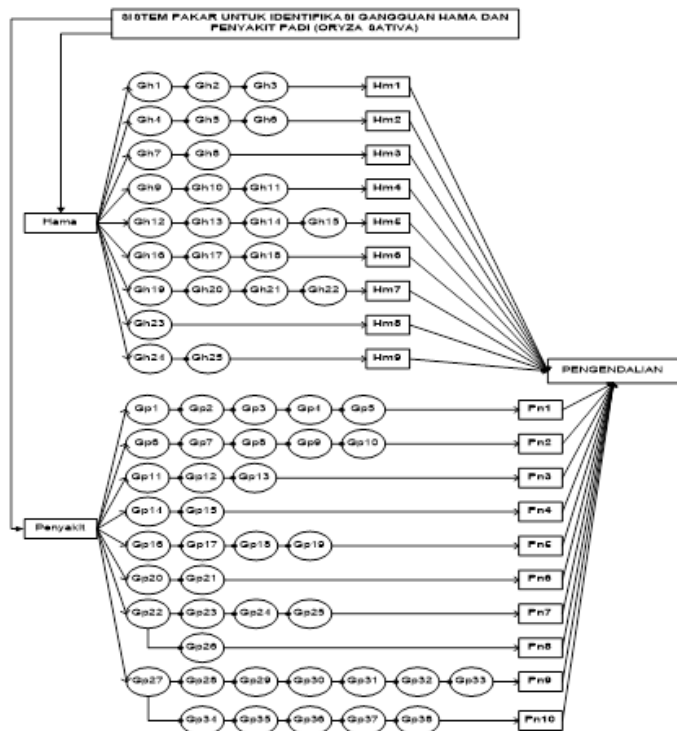

Gambar 4. Pohon Keputusan

Berdasarkan pohon keputusan pada Gambar di atas, maka dapat ditunjukkan bahwa aturan-aturan yang terjadi dalam sistem pakar ini yaitu sebagai berikut:

Tabel 4. Aturan (Rule)

\begin{tabular}{|c|c|}
\hline Kode & Rule (IF THEN) \\
\hline R1 & If $\mathrm{Gh} 1$ and $\mathrm{Gh} 2$ and $\mathrm{Gh} 3 \mathrm{Then} \mathrm{Hm} 1$ \\
\hline R2 & If $\mathrm{Gh} 4$ and $\mathrm{Gh} 5$ and $\mathrm{Gh} 6 \mathrm{Then} \mathrm{Hm} 2$ \\
\hline $\mathrm{R} 3$ & If Gh7 and Gh8 Then $\mathrm{Hm} 3$ \\
\hline R4 & If Gh9 and Gh10 and Gh11 Then $\mathrm{Hm} 4$ \\
\hline R5 & If Gh12 and Gh13 and Gh14 and Gh15 Then Hm5 \\
\hline R6 & If Gh16 and Gh17 and Gh18 Then Hm6 \\
\hline R7 & If Gh19 and Gh20 and Gh21 and Gh22 Then Hm7 \\
\hline R8 & If Gh23 Then $\mathrm{Hm} 8$ \\
\hline R9 & If Gh24 and Gh25 Then $\mathrm{Hm} 9$ \\
\hline R10 & If $\mathrm{Gp} 1$ and $\mathrm{Gp} 2$ and $\mathrm{Gp} 3$ and $\mathrm{Gp} 4$ and $\mathrm{Gp} 5$ Then $\mathrm{Pn} 1$ \\
\hline R11 & If Gp6 and $\mathrm{Gp} 7$ and $\mathrm{Gp} 8$ and $\mathrm{Gp} 9$ and $\mathrm{Gp} 10$ Then $\mathrm{Pn} 2$ \\
\hline R12 & If $\mathrm{Gp} 11$ and $\mathrm{Gp} 12$ and $\mathrm{Gp} 13$ Then $\mathrm{Pn} 3$ \\
\hline R13 & If Gp14 and Gp15 Then Pn4 \\
\hline R14 & If Gp16 and Gp17 and Gp18 and Gp19 Then Pn5 \\
\hline R15 & If Gp20 and Gp21 Then Pn6 \\
\hline R16 & If Gp22 and Gp23 and Gp24 and Gp25 Then Pn7 \\
\hline R17 & If Gp22 and Gp26 Then Pn8 \\
\hline R18 & $\begin{array}{l}\text { If Gp27 and } \mathrm{Gp} 28 \text { and } \mathrm{Gp} 29 \text { and } \mathrm{Gp} 30 \text { and } \mathrm{Gp} 31 \text { and } \mathrm{Gp} 32 \text { and } \mathrm{Gp} 33 \text { Then } \\
\mathrm{Pn9}\end{array}$ \\
\hline R19 & If $\mathrm{Gp} 27$ and $\mathrm{Gp} 34$ and $\mathrm{Gp} 35$ and $\mathrm{Gp} 36$ and $\mathrm{Gp} 37$ and $\mathrm{Gp} 38$ Then $\mathrm{Pn} 10$ \\
\hline
\end{tabular}

Diagram Konteks (Context Diagram) mengambarkan hubungan input/output antara sistem dengan dunia luarnya. Pada diagram konteks ini terdapat dua entitas yaitu Pakar dan User. Seperti pada entitas Pakar melakukan entri data Penyakit, Hama, Gejala, dan data Pengendalian, kemudian menerima hasil proses seperti informasi Penyakit, Hama, Gejala, dan data
Pengendalian serta informasi data aturan . Untuk entitas user, hanya menerima hasil diagnosa dari konsultasi yang dilakukan.

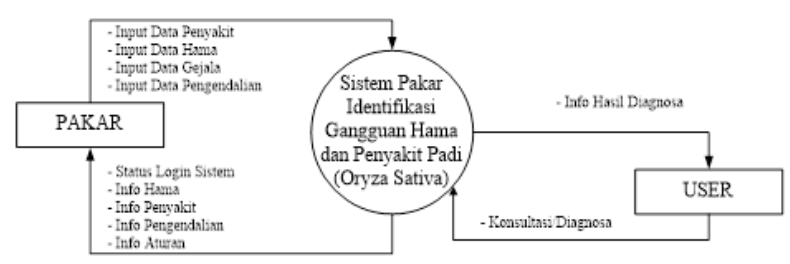

Gambar 5 Konteks Diagram SP Oryza Sativa

Sativa

Data Flow Diagram Level 0 SP Oryza

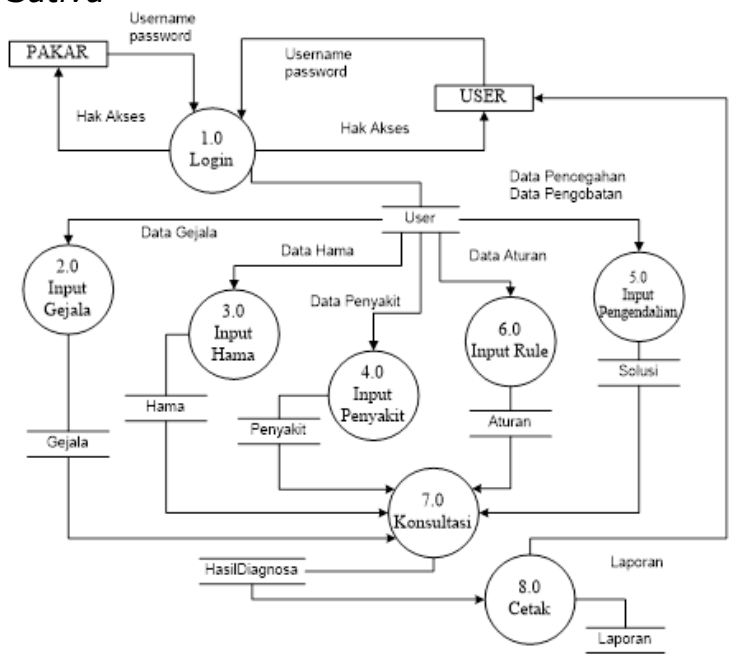

Gambar 6. DFD Level 0 SP Oryza Sativa

\section{Implementasi Sistem}

Menu Utama ini biasa juga disebut dengan formhome bagian ini berisikan menumenu yang memiliki link ke modulmodul program lainnya. Untuk penggunaannya hanya perlu memilih menumenu atau sub menu yang terdapat pada gambar dibawah ini.

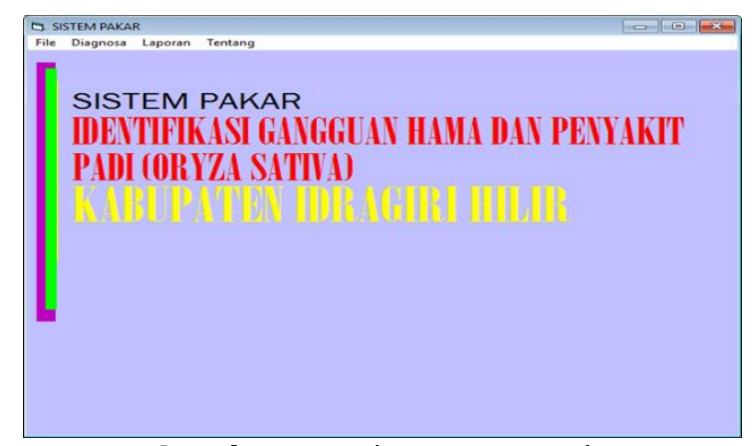

Gambar 7 Halaman Beranda

Form yang digunakan untuk melakukan diagnosa penyakit pada tanaman padi yang digunakan untuk melakukan 
konsultasi. Untuk melakukan konsultasi ini pengguna hanya diminta untuk memasukkan nomor ID dan selanjut nya memilih pertanyaan pengetahuan ataupun gejalagejala dengan menceklis Ya pada akhir pertanyaan, kemudian menekan tombol berikutnya untuk mengetahui hasil diagnosa yang didapatkan

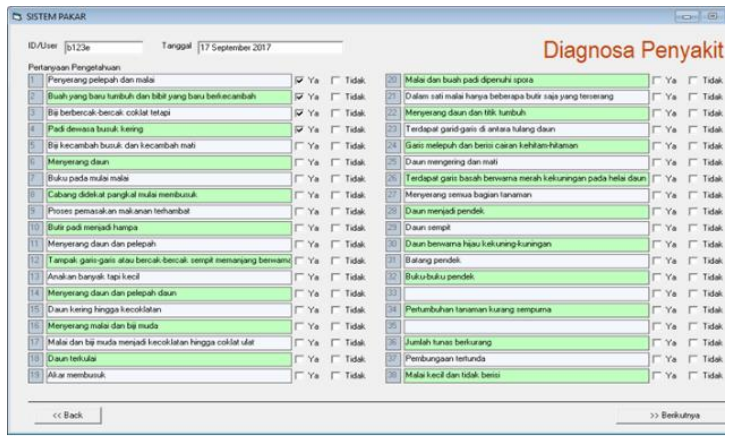

Gambar 8. Form Diagnosa

Form input data penyakit ini digunakan untuk menginputkan data penyakit, yaitu dengan menginputkan kode penyakit dan nama penyakit. kemudian menekan tombol simpan maka data akan tersimpan dan akan ditampilkan pada listview pada form input data penyakit ini, form ini juga dilengkapi dengan tombol, update dan batal.

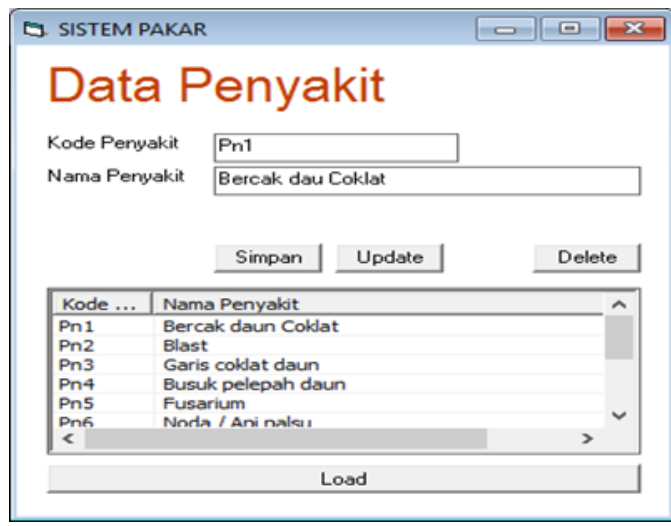

Gambar 9 Form Data Penyakit

Form data gejala penyakit ini digunakan untuk menginputkan data gejala penyakit, yaitu dengan menginputkan kode gejala penyakit dan nama gejala penyakit. Untuk prosesnya dapat dilihat pada gambar berikut ini.

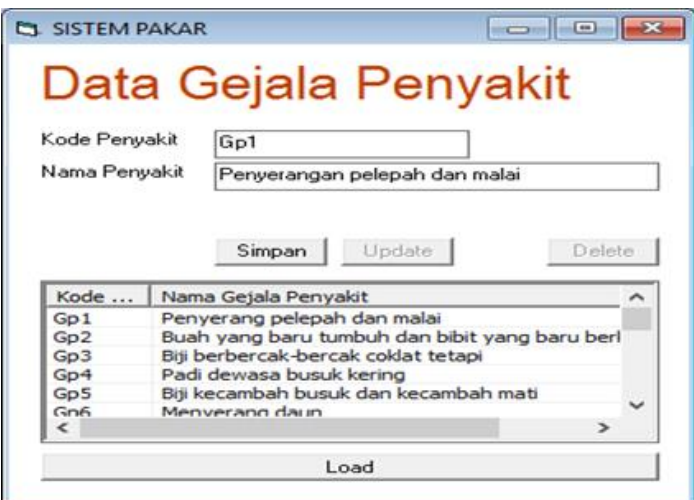

Gambar 10 Form Data Gejala Penyakit

Form data pengendalian penyakit ini digunakan untuk menginputkan data pengendalian penyakit, yaitu dengan menginputkan ID, nama penyakit, penyebab, dan pengendalian. Untuk prosesnya dapat dilihat pada gambar berikut ini

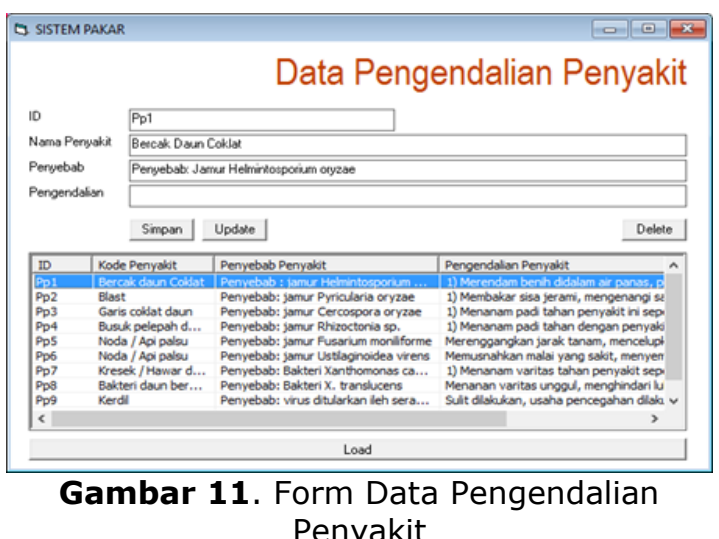

Form ini digunakan untuk menginputkan data pengendalian penyakit, yaitu dengan menginputkan ID, nama penyakit, penyebab, dan pengendalian, kemudian menekan tombol simpan maka data akan tersimpan dan akan ditampilkan pada listview pada form data pengendalian penyakit ini, form ini juga dilengkapi dengan tombol, update dan batal. Untuk prosesnya dapat dilihat pada gambar sebagaimana berikut ini:

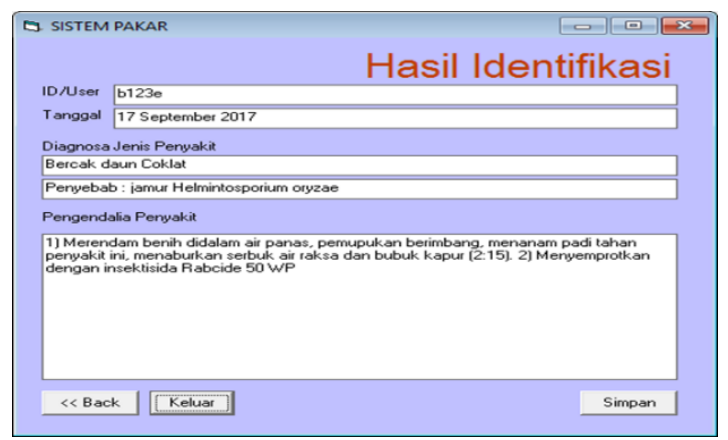

Gambar 12. Hasil Identifikasi 


\section{KESIMPULAN DAN SARAN}

Berdasarkan hasil penelitian yang telah dilakukan, maka dapat ditarik beberapa kesimpulan:

1. Sistem dapat membantu mempermudah masyarakat dalam mendeteksi kerusakan tanaman padinya yang disebabkan karena adanya gangguan hama dan penyakit.

2. Sistem ini dapat membantu dalam memberikan penanganan terhadap diagnosa dikarenakan sistem telah menyimpan semua pengetahuan mengenai hama dan tanaman padi ke dalam database.

3. Dengan adanya sistem pakar identifikasi hama dan penyakit pada tanaman padi ini mampu memberikan hasil diagnosa berdasarkan gejala yang yang ditemukan. Penerapan metode forward chaining mampu menjawab permasalahan masyarakat dalam menganalisis jenis penyakit ataupun hama yang menyebabkan kerusakan pada tanaman padi berdasarkan pengetahuan yang dikumpulkan.

Dari beberapa kesimpulan yang telah diambil, maka dapat dikemukakan saransaran yang akan sangat membantu untuk pengembangan sistem ini selanjutnya

1. Perlu dipertimbangkan untuk menambah gejala dan jenis hama dan penyakit pada tanaman padi yang bisa didiagnosa, agar sistem pakar ini lebih baik.

2. Diharapkan sistem ini dapat dikembangkan sehingga dapat digunakan untuk mendiagnosa berbagai macam penyakit (tidak sebatas penyakit pada tanaman padi).

3. Pada penelitian ini programnya berbasis stand alone, diharapkan dapat dikembangkan menjadi online atau berbasis web agar masyarakat umum dapat langsung mengetahui tentang hama dan penyakit pada tanaman padi dan cara penanganannya.

\section{DAFTAR PUSTAKA}

[1] Albahra. (2005), "Analisa dan Desain Sistem Informasi". Yogyakarta : Graha Ilmu

[2] Jogiyanto. 2005. Analisis \& Desain Sistem Informasi. Yogyakarta : Andi

[3] Kusrini. 2009. Membangun Sistem Informasi Akuntansi Dengan Visual Basic dan Microsoft SQL Server.

[4] Nugroho, Bunafit. 2014. Panduan Membuat Aplikasi Inventory Barang.Jakarta : Elex Media Komputindo
[5] Rosa A.S, M. Shalahuddin. Rekayasa Perangkat Lunak Terstruktur dan Berorientasi Objek. 2013. Informatika Bandung : Bandung

[6] Sunyoto, Andi. 2007. Pemrograman Database dengan Visual Basic dan Microsoft SQL.Yogyakarta : Andi

[7] Sutabri, Tata. 2012. Konsep Dasar Sistem Informasi. Yogyakarta : Penerbit Andi

[8] Sutojo, Mulyanto, Suhartono. (2011), "Kecerdasan Buatan", Yogyakarta: Penerbit Andi 